\title{
8. Paul Robeson's visit to Australia and Aboriginal activism, 1960
}

\author{
ANN CURTHOYS
}

Paul Robeson, a famous African American singer with a deep bass voice who brought a dramatic opera singing style to popular songs and was best known for his rendition of the timeless 'Ol' Man River', visited Australia in October and November 1960. The Australian Peace Council had invited him in 1950; soon afterwards, the United States government had confiscated his passport because of his communist sympathies and loyalty to the Soviet Union. ${ }^{1}$ When his passport was returned in 1958, Paul Robeson and his wife Eslanda went on many singing tours, in an effort to earn some of the money lost during the hard unfriendly years of the 1950s, and to advocate a number of political causes international peace, workers' rights, and gender and racial equality. The last of those tours was to Australia and New Zealand. This chapter is an account of that tour, especially as it related to Indigenous people and political activism around Indigenous rights.

Paul Robeson had always led an international life, as a performer and political figure, in a spirit of internationalism that characterised his generation of radical African Americans. It is a spirit that I also recognise in my own communist family upbringing; as in many communist households in the middle decades of the twentieth century, my mother had a particular fondness for Paul Robeson and often played his records. I especially remember that she had a record of the infamous Peekskill concert of September 1949, which was violently broken up by anti-communists after Robeson had sung to 20,000 sympathisers. Living in Newcastle, which Robeson did not visit, I did not hear or see Paul Robeson myself, but I was keenly aware in a more general sense of his importance in Left-wing circles. I first thought of studying his Australian tour in detail when researching for my book, Freedom Ride: a Freedom Rider Remembers (2002),

\footnotetext{
1 See mention of an invitation from the Australian Peace Council for its conference in April 1950, in the Argus, 22 June 1950, copy held in 'Paul Robeson and Madam Sun Yat Sen - Proposed visit', National Australian Archives [hereafter NAA], Series A33, Control Symbol 1950/2/2697. See also letter on Council on African Affairs, Inc letterhead from Paul Robeson to Nance Macmillan, Australian Peace Conference, 330 Little Flinders Street, Melbourne, on 27 June 1950, regretfully declining an invitation to the Melbourne Conference that year: 'Paul Robeson', Connie Healy collection, Fryer Library, UQFL 191.
} 
which traced the history of the Australian Freedom Ride of 1965. In the course of that research, a number of the freedom riders mentioned that they had been influenced by hearing Robeson sing in $1960 .^{2}$ I was intrigued, and eventually decided to explore the visit in detail. My larger concern in researching and writing this essay is to understand how a politics of racial equality emerged in the context of, and ultimately helped change, the politics of the Cold War.

One of the best-remembered episodes of the tour occurred in Sydney. At a private screening in the function room of his hotel in Sydney, Robeson saw a film featuring Indigenous Aboriginal people. ${ }^{3}$ One of those present was Faith Bandler, an Australian of Pacific Islander descent who is now well known as a key figure in the campaign for Indigenous rights and especially for the Yes vote in the referendum of 1967 to change the Australian constitution. She recalled the event over 30 years later:

I had an occasion to meet him, after meeting him at the airport, and to show him a film that was made on the Warburton Ranges. And I shall never forget his reaction to that film, never. It was a film taken on a mission station where the people were ragged and unhealthy and sick, very sick. And we took this film and we showed it to him. He was staying in the Hotel Australia and we showed him the film and Paul then was wearing a black cap on his head, to keep his head warm. He was no chicken then, of course, and Islanda [sic] always insisted that before a concert he should rest that day, but she allowed him to come down and have a look at the film, in the Starlight Room, as they called it, in the Hotel Australia and as he watched the film the tears came to his eyes and when the film finished he stood up and he pulled his cap off and he threw it in his rage on the floor and trod on it and he asked for a cigarette from someone. Well a lot of people smoked in those days so there was no shortage of cigarettes and Islanda said to me, 'Well it's many years since I've seen him do that'. He was so angry and he said to me, 'I'll go away now, but when I come back I'll give you a hand'. He was beautiful, but he died and he didn't come back. ${ }^{4}$

This account is becoming legendary, perhaps partly because it is readily available on the internet. In July 2009, journalist Shane Maloney evoked it in a short piece with the title 'Faith Bandler and Paul Robeson' in The Monthly magazine. ${ }^{5}$ Moving and informative as it is, Bandler's account is necessarily partial; indeed,

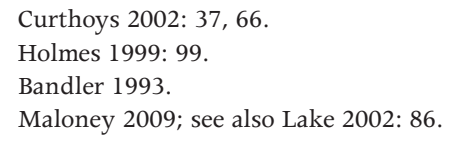


it is a small part of a larger story. Here, using documentary, visual, aural, and oral history sources, I explore this larger story, asking what Paul Robeson's visit meant, both at the time and since, for Indigenous people. ${ }^{6}$

\section{Paul Robeson, performer and political activist}

African-American connections with Indigenous people in Australia have a long history. These interactions have been both political and cultural. John Maynard has drawn attention to the political influence of the Marcus Garvey movement on Aboriginal waterside workers in the early twentieth century. ${ }^{7}$ Culturally, there have been influences through dance, but one of the main sites of connection has been music, more specifically through singing. Gospel and hymn singing was much encouraged on many evangelical missions, and visits by entertainers, including African American entertainers, were quite common. ${ }^{8}$ These visits go back to the nineteenth century; for example, the Fisk Jubilee singers, an a cappella ensemble of Fisk University students known especially for their singing of spirituals, visited the Maloga Mission in $1886 .{ }^{9}$ These connections persisted into the twentieth century, and from the 1950s especially, a series of African American entertainers visiting Australia met with and performed for Aboriginal people. Pastor Doug Nicholls encouraged a number to come to his Gore Street Church of Christ in Melbourne, including Mattiwilda Dobbs, an African American opera singer, Harry Belafonte, and pianist Winifred Atwell. ${ }^{10}$ Harry Belafonte completed a major tour of Australia just two months before Robeson, in August 1960, ${ }^{11}$ and Marian Anderson came soon after, in 1962. ${ }^{12}$ Odetta, an American singer best known for her rendition of 'O Freedom' at the March on Washington in 1963, visited in $1965 .{ }^{13}$ Such visiting singers seem to have sought out Aboriginal people; Margaret Valadian, one of the Indigenous people who met Paul Robeson in 1960, remembers that she 'also met with

\footnotetext{
6 The most detailed account of the Robeson tour of Australia and New Zealand so far is in Duberman 2005[1988]. His four-page account relied on newspaper sources, Mrs Robeson's letters back to her family, and some material sent to him by an Aboriginal rights lawyer, Lloyd Davies, based in Perth. He was unable to visit Australia, however, and he wrote to me recently saying he was delighted I was doing this project, as he was conscious the Australian and New Zealand part of the story deserved further research: 'I never got around to travelling to Australia; by then, I guess, I was plain worn out!'

7 Maynard 2007: ch 3, 'Inspiration and Influences'.

8 Dunbar-Hall 2004: 41-42.

9 Abbott and Seroff 2002: 3-27.

10 Australian Broadcasting Commission 1955. See also Broome 2005: 290-291; Costa 2006 : 77.

11 Belafonte was featured on the cover of Woman's Day on 15 August 1960. For an account of his Brisbane concert on 24 August 1960, see Courier Mail, 25 August 1960: 3.

12 Keiler 2002: 302-304.

13 Roadknight 2001.
} 
Marian Anderson and Odetta when they came to Brisbane'. The 'Go Tell it on the Mountain Singers', who were touring in early 1965, farewelled the Freedom Riders when they left the University of Sydney on 12 February $1965 .{ }^{14}$

While a number of these visitors were involved in the Civil Rights movement and had strong political convictions, no visit was more political than Paul Robeson's. Robeson was throughout his life a deeply political and often controversial figure. Born in 1898, his father was a former slave who had become a Presbyterian minister, while his mother came from a prominent African American Philadelphia family. After studying at Rutgers University, where he became a well-known college footballer, and Columbia University, where he studied law, he turned to acting. He became famous for his lead roles in several Eugene O'Neill plays, and then Shakespeare, his Othello the first acted by an African American for over a century. From there he moved to singing, with huge record sales internationally in the 1930s and 1940s, including in Australia. He also acted in a number of films, and through records and film became popular in Europe as well as the United States. Despite his pro-Communist politics, he remained popular in the United States during World War II, when the Soviet Union and the United States were allies. His Broadway Othello in 1942-1943 was an enormous success, and in its wake came a number of major honours and awards, such as the Abraham Lincoln Medal for 'notable services in human relations'. ${ }^{15}$

After the war, however, with the tensions between the United States and the Soviet Union growing, Robeson faced a quite different political environment. He stubbornly insisted on his support for the Soviet Union, often saying that it was the first country to treat him simply as a human being. Like many Communists, he refused to believe the negative reports of the Soviet Union were true, seeing them as disinformation spread by the Soviet Union's enemies. In 1949, he attended a World Peace Congress in Paris, and was reported to have said that African Americans would not support the United States if war broke out between the United States and the Soviet Union. This comment, which Duberman argues was misquoted (he had actually said, 'We shall not make war on anyone. We shall not make war on the Soviet Union'), was a major source of his subsequent ostracism. ${ }^{16}$ In 1950, his Communist and Soviet sympathies led to the United States government depriving him of his passport. Trapped within the United States in a hostile atmosphere, he found his performance opportunities drying up, with concerts cancelled and recordings withdrawn from sale.

14 Tribune, 24 February 1965: 1.

15 Duberman 2005[1988]: 281.

16 Duberman 2005[1988]: 341-342; Beeching 2002: 339-354, esp 341. 
The restrictions on Robeson's travels abroad during the 1950s have an interesting context. As Mary Dudziak writes in her book, Cold War, Civil Rights, African Americans were important to the United States attempt in the context of the Cold War to counter Soviet and other accusations of racial repression and subordination. 'African Americans travelling abroad could bear witness to the character of American equality' ${ }^{17}$ Those who could be trusted to say the right thing from the government's perspective found their way eased; those, like Robeson, who could not, were blocked in various ways. Other African American political leaders who found their ability to travel overseas curtailed in the 1950s included the veteran WEB du Bois, and others like Louis Armstrong were closely monitored. ${ }^{18}$

His performance opportunities now limited, Robeson became a political activist within the United States. He continued to work closely with Communist organisations and allied peace organisations. He was prominent in the Civil Rights Congress, a controversial and vigorous Communist-led organisation that fought for African American rights in the Cold War period. ${ }^{19} \mathrm{He}$ was a leading figure in the Civil Rights Congress's 'We Charge Genocide' petition of December 1951, submitting it to the UN Secretariat in New York at the same time as William L Patterson, the petition's main author, submitted it to the UN General Assembly in Paris. ${ }^{20}$ Presented only 11 months after the UN Genocide Convention went into effect, the petition argued that the lynching and other forms of assault on the lives and livelihood of African Americans from 1945 to 1951, especially the frenzied attacks on returning Black American veterans, amounted to genocide. ${ }^{21}$ In addition to skilled legal challenges, the Civil Rights Congress engaged in picketing, demonstrations and petitioning, for example in the cases of Willie McGee, Rosa Lee Ingram, the Trenton Six, and the Martinsville Seven. ${ }^{22}$ The Civil Rights Congress strongly believed that a focus on Jim Crow laws and deprivation of Blacks' rights would be an embarrassment for the United States abroad and might hasten overdue reform. It was to be proved right in this judgment; and the American Civil Rights movement a decade later successfully adopted these CRC tactics. ${ }^{23}$ The Civil Rights Congress itself, however, collapsed in 1956, its close association with Communism too disabling for a role in the new Civil Rights movement, which was anxious to

17 Dudziak 2000: 61.

18 Dudziak 2000: 61-62, 66.

19 Horne 1988: 13-21, 48, 69.

20 Patterson 1971: 184; Horne 1986.

21 Civil Rights Congress 1951: 8. See also Curthoys and Docker 2008.

22 Horne 1988: 13-21, 48, 69.

23 Dudziak 2000; Von Eschen 1997. 
distinguish itself from the Communist-influenced African-American politics of a decade earlier. ${ }^{24}$ Earlier leaders were set aside and a new generation emerged. Robeson, with his Communist associations, was seen as a liability. ${ }^{25}$

For Robeson personally, however, the worst was over by 1958 when his passport was returned; in that year, he returned to prominence triumphantly with a concert at Carnegie Hall. ${ }^{26} \mathrm{He}$ based himself in London and travelled widely in Europe and Africa. In 1960, he agreed to undertake a commercial tour of Australia and New Zealand, in a bid to make money after the years of effective blacklisting in the United States. The offer of more than $\$ 100,000$ for 20 concerts, with opportunities to earn more through television appearances, was too good to refuse.

\section{The Australian tour, October - December 1960}

Over an eight week period from early October to early December there were 12 Australian concerts - four in Sydney, three in Melbourne, two each in Adelaide and Perth, and one in Brisbane, plus several in New Zealand. The tour was organised commercially through a Sydney-based music entrepreneur, DD O'Connor Productions Ltd, of Sydney, in association with RJ Kerridge. In each city, the concerts were sold out or largely so, and attracted extremely enthusiastic audiences. There were at least two different programmes, possibly more. In each, there were three sets of songs, divided by Janetta McStay's piano solos. In the first programme, the first set included opera and classical songs such as Handel's 'Art Thou Troubled?', 'The Ode to Joy' from Beethoven's Ninth Symphony, and Schubert's 'Cradle Song' and the second set consisted of Negro spirituals including 'Joshua Fit De Battle ob Jericho' and 'Swing Low, Sweet Chariot'. The last set consisted of songs from around the world - the 'Volga Boatman's Song', 'Water Boy', and the Scottish 'Eriskay Love Lilt'. The second programme had a similar structure, and its best-known songs included 'Didn't My Lord Deliver Daniel', 'Steal Away', and 'Goin' Home'.

The opening concert in Brisbane's Festival Hall on 15 October attracted an almost capacity audience of 5000 people, and the audience loved it. The Robesons then went to New Zealand for almost three weeks, where Paul met Maori on several occasions and expressed concern at their mistreatment and suppression of their culture. They returned to Sydney on 3 November; Paul Robeson performed four concerts there, on 7, 8, 12 and 14 November. There were three concerts in Melbourne - on 16, 18 and 22 November, two in Adelaide on 24 and 27 November, with the final two concerts in Perth on 1 and 3 December. There were

24 D'Emilio 2003: 178-179.

25 See Beeching 2002: 353.

26 Tribune, 12 October 1960: 7. 
several television appearances, including one on a Sunday night programme called 'Spotlight' on ABC television, recorded on 5 November. ${ }^{27}$ Robeson also appeared on the Christmas show of 'Hal Lashwood's Minstrels', broadcast on 15 December, where he sang 'Silent Night' and other songs to a group of children.

In his biography, Martin Duberman emphasises the testy confrontation between Robeson and reporters at his first Sydney press conference. ${ }^{28}$ Overall, though, press coverage of his tour was largely sympathetic. Newspapers that would usually have been savage in their denunciation of anyone who defended the Soviet Union the way Robeson did treated him with respect and even in some cases liking and admiration. This was evident even before his arrival. The Sydney Morning Herald carried a story from its London Correspondent that spoke of his 'easy charm', and his eminence as a singer. When he lost his passport in the 1950s, the correspondent wrote, his friends deserted him: 'They forgot the highness of his heart, the generosity of his mind, his incomparable talents, and remembered only his political naivete' ${ }^{29}$ The Daily Telegraph was also reasonably sympathetic, saying few questioned Robeson's sincerity, though they might disagree with his politics, and concluded the story by saying 'Robeson is at his best singing melancholy songs', perhaps because he was, as the story's headline had it, the 'loneliest man in show business' ${ }^{30}$

Once the tour was under way, the positive reception continued. The concerts themselves were favourably reviewed. The Courier Mail reported that the Brisbane concert was 'greatly to the taste' of its audience. The reviewer liked his 'organ-like richness of tone, and the tremendous resonance in the lowest register' ${ }^{31}$ The Sunday Mail reviewer reported, 'We heard spirituals sung with a properly religious fervour; and heard and saw an audience give a demonstration of something like hero worship.' ${ }^{32}$ The Sydney Morning Herald reviewer, Ray Castles, said of the first of the four Sydney concerts that its extra-musical qualities were every bit as important to the total experience of the evening as the sounds produced by Robeson the singer'. Castles noted 'the enormous aura of benevolence and goodwill generated by his presence; an aura in which large and resounding concepts like freedom and amity, whether expressed in song

\footnotetext{
27 The evidence for his television appearances is very sketchy. 'Paul Robeson', FBI Report, NY 100-25857: 2351, refers to television interviews in Adelaide. The next page summarises some of the responses to Robeson in Adelaide, including one in the Adelaide News, 16 November 1960, 'What a fine man Paul Robeson looked and sounded in Sunday's "Spotlight", on Channel 2', viewed 5 October 2009:

$<$ http://news.lp.findlaw.com/legalnews/entertainment/fbi/robes/robes02352.html>

28 Duberman 2005[1988]: 487-488.

29 Sydney Morning Herald, 9 October 1960: 106.

30 Daily Telegraph, 9 October 1960: 10.

31 Courier Mail, 17 October 1960: 10.

32 Sunday Mail, 16 October 1960.
} 
or speech, seemed to tingle with new relevance'. He gives us an inkling of why responses were so positive when he went on to say that while the voice was familiar from films and recordings, hearing it in person was still a shock.

It is as if the ground were to quake in musical terms, as if a sudden fissure had opened to reveal some subterranean reservoir of resonant darkness. This cosmic belch of a voice still has the power to astonish by sheer carpeted magnificence. ${ }^{33}$

Music reviewers made these kinds of comments throughout the tour. The Adelaide Advertiser reviewer, John Horner, was delighted with the tremendous success of the evening; he described the concert as a 'fine celebrity concert' behind which was the theme of universal brotherhood. Robeson, he wrote, 'is simplicity itself on the stage ... confining himself in every song to the simplest of the eternal verities' ${ }^{34}$

The concerts were only part of the visit. Characteristically, Robeson had a political agenda as well - to meet with and give support to causes of peace and trade unionism. The arrangement of the more political aspect of the visit seems to have begun when Bill Morrow, of the Australian Peace Council and a former senator from Tasmania, met Robeson at a World Peace Council Bureau meeting in Moscow in 1959, and they discussed plans for the visit. ${ }^{35}$ Once Robeson arrived, the Peace Council and state-based Peace Committees, Waterside Workers Union, Building Workers' Industrial Union, and the Australia Soviet Friendship societies all played a role in organising welcomes, social functions, and political meetings. ${ }^{36}$ The Union of Australian Women organised in each city very well attended, successful, and well-reported events for Robeson's wife, Eslanda. An anthropologist, who had undertaken fieldwork in Africa, and the author of African Journey, ${ }^{37}$ Eslanda was a major figure. Throughout the tour, she gave separate press interviews and emphasised the role of women in struggles for racial equality and peace. ${ }^{38}$ Her talk to the Union of Australian Women branch in Perth was typical; the topics there were, in the words of the ASIO Agent's report, 'The Negro problem throughout the world; Peace; Africa and the Congo; The United Nations; Equal rights and power to vote for American Negroes; and The rights of the Australian aboriginal' ${ }^{39}$

\footnotetext{
33 Sydney Morning Herald, 8 November 1960: 6.

34 Horner 1960: 11.

35 Johnson 1986: 275, 277.

36 See Anon 1961, 'Paul Robeson', Australian Security Intelligence Organisation (ASIO) Report, 9 March 1961, NAA, A6122/44 (1450)

37 Courier Mail, 15 October 1960: 13; Robeson 1945.

38 Her talk to the Melbourne audience of 400 women is reported in the Melbourne Communist newspaper, The Guardian, 24 November 1960: 8.

39 Australian Security Intelligence Organisation, Union of Australian Women, ASIO Report No 60/779: 62, series number A6119 (2006/00328495), Control Symbol 3873, ASIO, NAA.
} 
There were innumerable meetings, receptions, impromptu concerts, garden parties, and luncheons, all of which had some kind of political or social purpose. At these events, Robeson sang, but because of the conditions of his commercial contract, this was always without musical accompaniment. The best remembered occasion on which this happened was Robeson's visit to the Sydney Opera House building site on 9 November. At the invitation of the Building Workers' Industrial Union, Bill Morrow of the Australian Peace Council took him there. As the Daily Telegraph reported, he talked to more than 250 workmen in their lunch hour, telling them they were working on a project they would be proud of one day. The workers sat on 'tiles, pipes, timber and scaffolding', and later mobbed Robeson for autographs. He also sang. ${ }^{40}$ Wearing a large coat, he cupped his ear and sang solo to the building workers on site. Robeson himself said the day after his visit,

Yesterday, I went down by the Opera House, standing around singing to the workers ... I could see, you know, we had some differences here and there. But we hummed some songs together, and they all came up afterwards and just wanted to shake my hand and they had me sign gloves. These were tough guys and it was a very moving experience. ${ }^{41}$

Many people have recalled this event since. One was John Aquilina, a Minister in the NSW Labor Government, who informed parliament on 20 October 1998 that his father had been a carpenter working on the Opera House site, and had been there that day. 'Dad told us that all the workers - carpenters, concreters and labourers - sang along and that the huge, burly men on the working site were reduced to tears by his presence and his inspiration' ${ }^{42}$ One reason the event is so well remembered is that it was recorded on film by Howard Rubie, a cinematographer with Cinesound, with both vision and sound of exceptional quality. ABC television has screened the film many times since.

Robeson sang to large meetings of waterside workers in Sydney, Melbourne, and Adelaide. On 10 November, he sang to a stop work meeting of thousands of workers at the Sydney Town Hall, called by the Waterside Workers' Federation to protest against the Crimes Bill, then before Parliament. The union's newspaper later commented, 'He made it the best stop work meeting ever'.$^{43}$ In Melbourne, the union held a stop work meeting on the seventh day of what became a tenday stoppage, initially over the right to load ship stores, and then a protest against suspension threats and the cancelling of leave credits. As in Sydney, Robeson received a tumultuous reception. The Maritime Worker reported that

\footnotetext{
40 Daily Telegraph,10 November 1960: 15; Tribune, 16 November 1960: 10.

41 Transcript made by Sari Braithwaite from recording made of Robeson's speech at Paddington Town Hall, 10 November 1960.

42 NSW Legislative Assembly, Hansard 1998.

43 Maritime Worker, 1 Dec 1960: 4; Sydney Morning Herald, 11 November 1960: 6.
} 
'Paul sang to the members the songs for which he is famous, Joe Hill, Water Boy, $\mathrm{Ol}^{\prime}$ Man River, and then led the 4000 present in John Brown's body, explaining that John Brown had died that his father, a slave, should be free'. There were unprecedented scenes when Robeson left the stadium, 'Members climbing over seats to grasp his hand and the whole gathering was on its feet, stamping, shouting, and clapping. It had to be seen to be believed' ${ }^{44}$ When he entered the Wharfies' hall in Port Adelaide for a lunchtime address and recital, the workers gave him a standing ovation. The Maritime Worker's Adelaide reporter, Jim Mitchell, wrote that he was greeted by '1,100 wharfies, tally clerks, seamen and their families who had gathered at lunch time to hear his address and impromptu recital'. The audience loved his songs and speeches, and 'the final "three cheers" at the end of the performance lifted the roof' ${ }^{45}$ Arthur Shertock wrote to me about this occasion.

On that day it was jam packed with not only wharfies and seamen but also with shop workers and people from offices and banks. ... The lunch hour was long gone; I guess it was after three o'clock when finally he concluded his magnificent performance, with no musical accompanists. [As] far as I could see no one had left the hall.

At these Waterside Workers' Federation events, Robeson was typically given an Aboriginal object of some kind, to signify the wharfies' support for Aboriginal rights. The Sydney branch of the Waterside Workers' Federation gave him a print of an Albert Namatjira painting. ${ }^{46}$ In Adelaide, the Waterside Workers' Federation gave him 'an authentic woomera throwing stick', which would 'remind him of his desire to learn more about the problems of the old Australians in our midst' ${ }^{47}$

\section{The Robesons and Indigenous people}

Paul and Eslanda Robeson seem to have sought out Indigenous people wherever they went. In Brisbane, even before the first concert of the tour, Robeson met with Margaret Valadian, then 24, an Aboriginal student who was intending to do a social studies course at the University of Queensland, and then do welfare work amongst Aboriginal people (all of which she later did). She was quoted in the Courier Mail as saying, 'I have always been greatly inspired by Mr Robeson's work in the cultural field, and I wanted to meet him'. ${ }^{48}$ She later attended his Brisbane concert, and went backstage afterwards to meet him. ${ }^{49}$ 'He autographed

44 Maritime Worker, 1 December 1960: 4.

45 Maritime Worker, 15 December 1960: 7.

46 Sydney Morning Herald, 11 November 1960: 6.

47 Maritime Worker, 15 December 1960: 7

48 Courier Mail, 15 October 1960: 1.

49 Truth (Queensland edition), 16 October 1960: 1. 
a copy of a 45rpm record for me', she recalled in 2008. ${ }^{50}$ Robert Anderson, now an Aboriginal elder in Brisbane, remembers attending the Brisbane concert at Festival Hall, and being on security duty to help make sure the Nazi Party did not interfere. ${ }^{51}$

In Sydney, Robeson met people through the Aboriginal Australian Fellowship, which had started four years earlier and involved both Aboriginal and non-Aboriginal activists, with Faith Bandler probably its best-known representative. ${ }^{52}$ Bandler reported to its December meeting that Eslanda Robeson had met Aboriginal people at La Perouse, an Aboriginal settlement in Sydney. ${ }^{53}$ The Fellowship also co-sponsored one of the major events of the tour. With the NSW Peace Committee, it organised a reception on Thursday 10 November for the Robesons at Paddington Town Hall. Fifteen hundred people were present, including about 30 Aboriginal people, whom the Aboriginal Australian Fellowship had helped to attend. ${ }^{54}$ Both Paul and Eslanda spoke, and Paul Robeson sang. Tom McDonald, the BWIU organiser responsible for getting Robeson to the Opera House, later recalled that

the place was crowded and he performed solo for a couple of hours without any musical instruments and it was one of the most remarkable performances by an individual I can recall. What he did was, you know, he talked about some of the struggles he'd been involved in. He'd then recite a bit of poetry. He'd then say a bit about his philosophies. ${ }^{55}$

Earlier that day, Robeson had attended the informal film screening recalled by Faith Bandler. The screening was organised by Helen Hambly, one of the nonAboriginal members of the Aboriginal Australian Fellowship, and Faith Bandler; also present was Alec Robertson, reporting for the Communist Party newspaper, Tribune. ${ }^{56}$ The film Bandler describes upsetting Robeson so much, known as Manslaughter when shown on television in 1957 but more commonly referred to simply as 'the Warburton Ranges film', was made by Bill Grayden, a Western Australian Member of Parliament. Grayden had in 1956 successfully pressed for an inquiry by the Western Australian parliament into 'Native Welfare Conditions in the Laverton-Warburton Range Area', an area affected by the British government's atomic bomb testing at Maralinga. The Inquiry's Report was extremely critical of the condition of the Yarnangu (the Aboriginal people

\footnotetext{
50 Letter Margaret Valadian to Ann Curthoys, 9 August 2008.

51 Robert Anderson to Sari Braithwaite, 2008.

52 Goodall 1996: 276-277.

53 I have, however, been unable to find any corroboration of this meeting at La Perouse, despite searching Aborigines Protection Board and other records. See the 'Minutes of Monthly General Meetings', Minute for 7 December 1960, AAF Papers, ML MSS 4057.

54 'Robeson will "fight for our Aborigines"', Sydney Morning Herald, 13 November 1960.

55 McDonald 1994. See also McDonald and McDonald 1998: 100-101.

56 Holmes 1999: 99-100.
} 
in that area) and received wide publicity; shocking many with its description of starvation and extreme deprivation. It was strongly criticised in the press, however, for giving a misleading and exaggerated account, and in response to his critics, Grayden returned to the area with a movie camera, accompanied by Pastor Doug Nicholls and other Western Australian parliamentarians. ${ }^{57}$ The resulting silent film, which lasts for just over 20 minutes, contained confronting images of Aboriginal poverty, starvation, injury, and disease in the Warburton and Rawlinson Ranges in the Central Aborigines Reserve, now known as the Ngaanyatjarra Lands. Doug Nicholls later told journalists: 'I wish I had not gone to the Warburton Ranges. I wish I hadn't seen the pitiable squalor, the sights of my people starving - the most shocking sights I have ever seen. Never, never can I forget. ${ }^{58}$

As Sue Taffe points out, activists used the ensuing film effectively for several years to alert other Australians to the injustices experienced by Aboriginal people and to press governments to take greater responsibility. ${ }^{59}$ By late 1960, when Hambly and Bandler showed the film to Robeson, the Fellowship had screened it many times, including at a Town Hall meeting in 1957 inaugurating the campaign for a referendum to change the Australian constitution. These screenings were usually to shocked non-Aboriginal audiences, but Fellowship members had also screened it to a meeting in the small New South Wales town of Walgett, which about 40 Aboriginal people attended, when making contact with local activists there. Over half those present signed the Fellowship petitions requesting a change to the constitution. ${ }^{60}$ It had also been shown on television in Sydney and Melbourne in May 1957. While many saw the film as proving Aboriginal poverty and suffering existed, others thought it was highly selective and misleading. Importantly, it did not present the views of the Yarnangu people about their own lives or about their being filmed in this way. Pam McGrath and David Brooks point out that Yarnangu both then and since have sought to stress their own agency and choices rather than the film's portrayal of them as victims of government neglect; many Yarnangu also see the film as a gross invasion of privacy. ${ }^{61}$ Nevertheless, the film was significant

\footnotetext{
57 Taffe 2008.

58 Victorian Aborigines Advancement League 1957, Analysis of Mr Rupert Murdoch's article [...], Melbourne: 2-3, as quoted in Attwood 2003: 150.

59 Taffe 2008.

60 Garland and McIlwraith 1957. Note that this report was the subject of much dispute within the AAF, mainly because it was feared that it contained defamatory material; Irene McIlwraith was expelled from the organisation for distributing the report without checking with the rest of the executive first. See also Fox and Bandler 1983: 65; McIlwraith, Irene to the Editor, Walgett Spectator, 18 September 1957, Walgett file, AAF Papers, ML MSS 4057/16.

61 McGrath and Brooks (forthcoming). Many thanks to Pam McGrath and David Brooks for allowing me to read this essay before its publication.
} 
in mobilising support for demands for Aboriginal rights, and played a role the formation of the Victorian Aborigines Advancement League and, indirectly, in the formation a year later of the Federal Council for Aboriginal Advancement. ${ }^{62}$

Though Bandler does not mention it, there was a second film screened in Robeson's hotel that day. This was a short film, People of Pindan, made earlier that year by Cecil Holmes, a pioneering Australian documentary filmmaker. People of Pindan was in fact the pilot for a much more ambitious project. On the suggestion of British documentary film-maker Paul Rotha, Holmes planned to make a feature-length film, The Flung Spear. While in Perth at the end of 1959, he met established Left wing Australian author, Gavin Casey, who had written a novel, Snowball (1958) and a play on Aboriginal themes. Casey alerted him to the cooperative movement that was becoming popular amongst Aboriginal people in Western Australia, Queensland, South Australia and New South Wales, and especially to the mining cooperative at Port Hedland, as evoked in Donald Stuart's novel, Yandy (1959). ${ }^{63}$ This was the Pindan cooperative, formed in the aftermath of the Pilbara pastoral workers' strike of 1946-9, led by tribal elders Clancy McKenna and Dooley Bin Bin along with white man Don McLeod. ${ }^{64}$ Intrigued by Casey's story, Holmes went to Port Hedland, stayed at Aboriginal camps, listened to songs, watched ceremonies by the campfire, and made a short film about the cooperative. It became the pilot for the larger project.

On Holmes' return to Sydney, plans for The Flung Spear advanced quickly. ${ }^{65}$ It was to be one hour in length, in colour, and would have three parts: the first would focus on Aboriginal workers in the pastoral industry, the second on Aboriginal fringe settlements, and the third on the co-operative movement. ${ }^{66}$ Gavin Casey and another successful Left wing author, Kylie Tennant, were to work with Holmes on the script, and a group of supporters formed a public company, Marngoo Films, expressly to raise the necessary finance. ${ }^{67}$ Helen Hambly, who had organised the screening for the Robeson's of the pilot film, People of Pindan, and her husband were closely involved in Marngoo Films, and perhaps one purpose of this screening was to gain Robesons of the pilot film, The Flung Spear project. (In fact, The Flung Spear was never made, but Holmes later sold the pilot to the $\mathrm{ABC} .^{68}$ )

\footnotetext{
62 Taffe 2008. See also Attwood 2003: 149-151; Taffe 2005: 34-36.

63 For information on the cooperative movement in New South Wales, see Goodall 1996: 299-307.

64 Hess 1994: 65-83.

65 Holmes 1960; Holmes 1999: 98-100. See also Williams 1999: 215, 1994: 36-39.

66 'News of the Day', The Age, 14 March 1960: 2.

67 Marngoo Films 1960. The secretary of the limited company was Sidney Lloyd Hambly, and Sidney and Helen Hambly were two of the listed eight subscribers.

68 Holmes 1999: 86-99; Holmes 1986: 57.
} 
Tribune reporter Alec Robertson reported Robeson's reaction to these two films:

When he saw two films - one showing the misery of tribal aborigines in a WA desert reserve, and the other showing confident and healthy tribal aborigines running their own mining cooperative at Pindan Robeson was beside himself with anger, compassion and determination to arouse more international action to assist the emancipation struggle of those he calls 'the indigenous people of Australia'. 'Why are you Australians tolerating that?' Robeson demanded. 'This is unbelievable. There is nothing primitive about these people's ability. There are no backward people anywhere - only people held back or forced back, by "overlords"".

'Australia', Robertson continued, will hear more of Paul Robeson on this issue' ${ }^{69}$

It was at the press conference after the Paddington Town Hall event that Robeson first spoke strongly about Aboriginal conditions and demands, and it seems very likely that his passionate comments were influenced by seeing the two films. He said he would return to Australia within six months to campaign for greater help for Aborigines and coloured people. 'If necessary, I will stomp up and down the country to help them', Truth quoted him as saying.

You have a serious problem here in Australia. I hope, and I feel certain, that Australia will do the right thing by the colored people. I have nothing but admiration for Australia. I feel at home here. It is my kind of country and I am sure you are my kind of people. ${ }^{70}$

Newspapers picked up the story, with headlines such as 'Australia has a colour problem says Paul Robeson' and 'Robeson will "fight for our Aborigines"”. ${ }^{71}$

By the time they reached Perth, both Robesons were increasingly voluble about Aboriginal rights, though it is unclear how much additional contact they had with Aboriginal people after the Paddington concert. In Melbourne, they met opera singer Harold Blair, and may have met other Aboriginal people as well, though I have found no evidence of formal events organised by Aboriginal rights organisations. ${ }^{72}$ When they arrived in Perth on 30 November, they were met by 200 cheering 'admirers from all walks of life', including a group of Aboriginal people, to whom Robeson said, 'I hope that soon they will treat you as well as they treat me'.$^{73}$ Non-Aboriginal supporters of Aboriginal rights were there

69 Tribune, 23 November 1960: 6. See also footnote 2 re accounts by Bandler.

70 Truth (Queensland edition), 13 November 1960: 11

71 Truth (Queensland edition), 13 November 1960: 11; Sunday Mirror (Sydney), 13 November 1960 : 9.

The Northern Territory News story was headlined “'I'll fight for the Aborigines" - Paul Robeson'; Northern Territory News, 15 November 1960: 3.

72 A search of the Council for Aboriginal Rights papers in the State Library of Victoria yielded nothing.

73 Tribune, 7 December 1960: 10. 
too; Lloyd Davies, a non-Indigenous lawyer and activist for Indigenous rights was there ${ }^{74}$ and noted Communist writer and public figure, Katharine Susannah Pritchard, author of Coonardoo, one of the first novels to depict Aboriginal characters sympathetically, gave a speech of welcome. ${ }^{75}$ At a press conference in Perth that evening, Robeson rejected the idea that Aboriginal people might not be ready for equal rights. 'The fact that these people are not given citizenship is indefensible and inexcusable. They are human beings, they have a right to live. ${ }^{76}$ He repeated the promise made in Sydney that he would return. At his huge concert at the Capitol Theatre the next day, he said from the stage, 'I am coming back to Australia as soon as I can and the first place I want to go is amongst my black brothers, the indigenous people of Australia' ${ }^{77}$

One of those at the concert was Colin Hollett, a railway union official. He approached Eslanda Robeson and through her invited Paul to sing the following day at the large railway workshops at Midland Junction. Paul agreed, but because of his Communist allegiance the works manager refused permission for the hastily organised concert to be held at the Workshops flagpole, the traditional site venue. Undaunted, and indeed welcomed by the Mayor of Midland Junction, Robeson sang at an open-air lunch hour concert on 2 December from the back of a truck at the entrance to the workshops. As the West Australian reported,

[m]ore than 2000 people jammed an entrance to the railway workshops to hear the Negro singer. Children climbed trees to get a better view ... Robeson sang Water Boy, Joe Hill, Ol' Man River and other American folk songs intermingled with classical themes, Chinese tunes and Shakespearian extracts. ${ }^{78}$

The Tribune reported the whole audience joining in the singing of 'John Brown's Body', just as they had done in Melbourne. ${ }^{79}$

Later that same day, at a Peace Council reception at the Palace Hotel, Robeson made, according to one ASIO report, 'a strong point of the Aboriginal problem and made many references to this theme throughout his address'. He is quoted as saying, 'the day will come and it will not be long when they WILL have equal rights'.$^{80}$ Another ASIO report (this event seems to have had at least three ASIO agents present) quotes Robeson: 'when I look at my darker brothers and

\footnotetext{
74 Anon, 'Lloyd Davies': <http://www.austlit.edu.au.ezproxy2.library.usyd.edu.au/run?ex=ShowAgent\& agentId $=\mathrm{A} \% 2 \mathrm{bO} 4>$

75 See Docker 1984: 30-33.

76 Tribune, 7 December 1960: 10.

77 Tribune, 7 December 1960: 10.

78 West Australian, 3 December 1960.

79 Tribune, 7 December 1960: 10.

80 'Paul Robeson - Welcomed at Afternoon Tea Party Organised by the Australian Peace Council (W.A. Division)', C/15/10, No 60/766, in file labelled Harold Godric Clements, ASIO, NAA, Series Number A6119.
} 
sisters in Australia and see them look just like my sister and my cousins and I say folks, well, oh, I'll have to come back here and start something here - try to get somebody interested' ${ }^{81}$

The Robesons left Australia, after another concert, on 4 December 1960. Several months later, Paul Robeson talked about his Australian visit to a German reporter in Moscow. He spoke enthusiastically, but then said:

One thing has embittered me. On the fifth continent I encountered a phenomenon which I have experienced in Africa and America: racial discrimination in the most loathsome form ... Here open extermination is effected. Here the public opinion in the world must go to work and say a serious word. I intend to return to Australia. I shall make films and give concerts. The proceeds shall benefit the aboriginal population languishing in poverty. I already did that in Africa, and now I want to repeat it once more in Australia. ${ }^{82}$

This reference to extermination reminds us of Robeson's role in the 1951 Civil Rights Congress's petition to the UN charging genocide against African Americans. In both cases, he saw people as confronting, but so far surviving, major threats to their existence as a people.

Paul Robeson never did come back, and in fact, this tour was to prove his last. By the time this interview was published, in April 1961, he was in a Soviet sanatorium suffering from severe depression, and he returned to the United States permanently in 1963. He gave a few low-key performances and then disappeared from public life until his death in 1976.

\section{Influence and memory}

The political influence of Robeson's tour on the movement for Indigenous rights is a little hard to estimate. It was, after all, part of a series of significant contemporary events and changes - the growth of political activism for Aboriginal rights, the thawing of the Cold War, and the increased influence of the American Civil Rights movement and of wider processes of decolonisation in Asia and Africa on Australian understandings of racial issues. African American freedom songs were important in influencing the consciousness of Australian Left wing students becoming interested in Aboriginal issues, especially the students involved in Abschol, Student Action for Aborigines, and the Freedom Ride of 1965. Former Freedomrider, Louise Higham, for example, told me that in her first year at the University of Sydney she had learned the powerful 'Jim Crow

81 'Australian Peace Council (WA Division), Visit of Paul and Eslanda Robeson', C/15/10, No 60/814, in file labelled Harold Godric Clements, ASIO, NAA, Series Number A6119.

82 Neue Zeit, 27 April 1961, as quoted in O'Reilly 1994: 378. 
must go' message from many of the songs she heard in the concerts organised by the Folk Music club. Oral history interviews indicate that those who heard or met Paul Robeson in 1960 were often deeply affected. Faith Bandler, already an activist, was strongly encouraged by his emphasis on the human rights of Black people around the world, and his quick understanding of the importance of the Aboriginal cause. ${ }^{83}$ Sue Johnston, another Freedomrider, told me that she had become interested in Aboriginal issues through hearing Paul Robeson sing in Sydney, as well as through her university study of race relations in American history.

The Robeson tour, now almost half a century ago, is surprisingly well remembered. For many people, their knowledge of the visit comes from a regularly repeated five minute short film on the $\mathrm{ABC}$, which featured Robeson singing at the Opera House. For others, it comes from Deep Bells Ring, a play written by Nancy Wills in 1987, which told the story of Robeson's life and career, including his Australian tour. Sponsored by the BWIU as an Art and Working Life project through the Theatre Board of the Australia Council, it toured Brisbane, Sydney, Canberra and Melbourne to enthusiastic audiences. Some Aboriginal people have been in these audiences, sometimes leading figures; when the production came to Sydney, Chicka Dixon and Gary Foley were listed among those present. ${ }^{84}$ In oral history interviews, it can be this play, as much as the original visit, that is now remembered. In Perth, in 2004, Robeson's singing to the workers from the back of a truck at the Midland Railway Workshops was commemorated with a free concert at the same site, featuring Perth baritone Andrew Foote singing many of the same songs that Robeson sang that day. On the centenary anniversary of Robeson's birth, in 1998, articles, radio programmes, and websites appeared commemorating Robeson and his visit. When giving papers on this project, those in the audience have often afterwards offered me many mementos such as programmes, and people have wanted to tell me they remember meeting or hearing Paul Robeson, perhaps shaking his hand. The emails sent to me and oral history interviews conducted by my research assistant, Sari Braithwaite, are often highly emotional, even after a space of almost 50 years. Nearly all of them have an intensely physical aspect, as people recall Robeson's voice, presence, size, colour, and handshake. They tend to stress Robeson's support for peace, and the trade unions, and some mention him in relation to Aboriginal rights.

These extremely positive memories, especially by people on the Left and in the performing arts, reinforce my sense that the visit of Paul and Eslanda Robeson was a huge success in its time. A few months after it was over, Jessie Street, a leading Aboriginal rights campaigner, wrote to Eslanda that '[t]hey are still talking about the visit of you and Paul out here', and the buzz and excitement

83 Lake 2002: 86-87.

84 The director Errol O'Neill supplied the author with a copy of his handwritten list of those attending. 
lasted a long time after that. ${ }^{85}$ Martin Duberman, relying on limited newspaper sources and especially on Eslanda's frank letters to her family detailing Paul's physical ailments, irritability, and periods of depression, tends to see it as a negative experience, indeed a 'grueling ordeal', and he seems to me to emphasise unduly the rare hostile press comments. ${ }^{86}$ While this was indeed still the Cold War, and there was, unsurprisingly, public questioning of Robeson's staunch support for the Soviet Union, overall this was a reaffirming cultural event for a wide range of groups on the Left and those of Left sympathy generally. Robeson's undeniable stature as a singer and performer to some degree took him out of the specific Cold War context of the time, as some newspaper reviewers recognised, making him a complex figure that could admired despite, as well as because of, his politics. Eslanda Robeson was an impressive speaker, who attracted positive responses wherever she went. This broader acceptance meant that the Robesons' support for the Aboriginal cause was a powerful encouragement for growing activism by Aboriginal people and their supporters over the next decade.

\section{Acknowledgements}

I acknowledge the help of my wonderful research assistant Sari Braithwaite, who has shown true detective skills in finding a range of printed sources including major daily and trade union newspapers, archival sources, and concert programmes, and who has conducted oral history interviews in Melbourne and Brisbane. I also wish to thank Brian Aarons, John Docker, and Frances PetersLittle for their assistance.

\section{References}

\section{Primary sources}

Anon 1950, 'Paul Robeson and Madam Sun Yat Sen - Proposed visit', Series A433, Control Symbol 1950/2/2697, National Australian Archives (NAA), Canberra.

Anon 1961, 'Paul Robeson', Australian Security Intelligence Organisation (ASIO) Report, 9 March 1961, A6122/44 (1450), NAA, viewed 5 October 2009: <http://naal2.naa.gov.au/scripts/Imagine.asp>

'Australian Peace Council (WA Division), Visit of Paul and Eslanda Robeson', C/15/10, No. 60/814, in file labelled 'Harold Godric Clements', Series Number A6119, ASIO, NAA, Canberra.

85 Street 1961.

86 Duberman 2005: 487. 
Australian Security Intelligence Organisation, 'Union of Australian Women', ASIO report no 60/779: 62, series number A6119 (2006/00328495), Control Symbol 3873, ASIO, NAA, Canberra.

Garland, W and McIlwraith 1957, 'Special Report and conclusions on interviews with the people of Walgett, NSW, and Impressions gained during the visit 6th to 10th September, 1957', Hannah Middleton Papers, ML MSS 5866/10, Mitchell Library, Sydney.

McIlwraith, Irene to the Editor, Walgett Spectator, 18 September 1957, Walgett file, AAF Papers, ML MSS 4057/16, Mitchell Library, Sydney.

Marngoo Films, Prospectus Marngoo Films Limited, Pearl Gibbs Collection, ML MSS 6922, Box 4, Mitchell Library, Sydney.

'Minutes of Monthly General Meetings', Minute for 7 December 1960, AAF Papers, ML MSS 4057, Mitchell Library, Sydney.

'Paul Robeson', Connie Healy collection, UQFL 191, Fryer Library, Brisbane.

'Paul Robeson', FBI Report, NY 100-25857: 2351, accessed 15 May 2010: <http:// news.lp.findlaw.com/legalnews/entertainment/fbi/robes/robes02352.html>

'Paul Robeson - Welcomed at Afternoon Tea Party Organised by the Australian Peace Council (W.A. Division)', C/15/10, No. 60/766, in file labelled Harold Godric Clements, Series Number A6119, ASIO, NAA, Canberra.

Robeson, Eslanda Goode 1945, African Journey, The John Day Company, New York.

Street, Jessie 1961, letter to Eslanda Robeson, 16 April 1961, carbon copy in 2.10 Correspondence 2300-2397, February-August 1961, in Series I, Correspondence 1951-1975, Council for Aboriginal Rights, MS 12913, State Library of Victoria, Melbourne.

\section{Secondary sources}

Abbott, Lynn and Doug Seroff 2002, Out of Sight: The Rise of African American Popular Music, 1889 - 1895, University Press of Mississippi, Jackson, Miss.

Anon, 'Lloyd Davies', Austlit (the Australian Literature Resources), accessed 5 October 2009: <http://www.austlit.edu.au.ezproxy2.library.usyd.edu.au/ru $\mathrm{n}$ ? ex $=$ Show Agent\&agentId $=\mathrm{A} \% 2 \mathrm{bO} 4>$

Attwood, Bain 2003, Rights for Aborigines, Allen \& Unwin, Sydney. 
Australian Broadcasting Commission 1955, Australian Broadcasting Commission Presents Mattiwilda Dobbs, Town Hall, Sydney, Saturday, 23 July 1955, 18 pp, annotated programme, accessed 2 October 2009: <http://www.dacapo. com.au/ausprog.html>

Bandler, Faith 1993, interview for ABC Television series, Australian Biography, 25 March 1993, transcript accessed 30 September 2009: <http://www. australianbiography.gov.au/subjects/bandler/interview6.html>

Beeching, Barbara 2002, 'Paul Robeson and the Black Press: The 1950 Passport Controversy', The Journal of African American History 87: 339-354.

Broome, Richard 2005, Aboriginal Victorians: A History since 1800, Allen \& Unwin, Sydney.

Casey, Gavin 1958, Snowball, Angus and Robertson, Sydney.

Civil Rights Congress 1951, We Charge Genocide: The Historic Petition to the United Nations for Relief from a Crime of the United States Government Against the Negro People, Civil Rights Congress, New York.

Costa, Ravi de 2006, A Higher Authority: Indigenous Transnationalism and Australia, University of New South Wales Press, Sydney.

Curthoys, Ann 2002, Freedom Ride: A Freedom Rider Remembers, Allen \& Unwin, Sydney.

— and John Docker 2008, 'Defining genocide', in The Historiography of Genocide, Dan Stone (ed), Palgrave, Houndmills, United Kingdom.

D'Emilio, John 2003, Lost Prophet: The Life and Times of Bayard Rustin, Free Press, New York.

Docker, John 1984, In a Critical Condition, Penguin Books, Ringwood.

Duberman, Martin 2005[1988], Paul Robeson: A Biography, The New Press, New York.

Dudziak, Mary L 2000, Cold War Civil Rights: Race and the Image of American Democracy, Princeton University Press, Princeton.

Dunbar-Hall, Peter 2004, Deadly Sounds, Deadly Places: Contemporary Aboriginal Music inAustralia, University of New South Wales Press, Sydney.

Fox, Len and Faith Bandler 1983, The Time was Ripe, Alternative Publishing Cooperative, Chippendale, New South Wales. 
Goodall, Heather 1996, Invasion to Embassy: Land in Aboriginal Politics in New South Wales, 1770 - 1972, Allen \& Unwin, Sydney.

Hess, Michael 1994, 'Black and red: the Pilbara pastoral workers' strike, 1946', Aboriginal History 18(1): 65-83.

Holmes, Cecil 1960, 'An Aboriginal film in colour is born', The Age Melbourne, 12 November 1960.

Holmes, Cecil 1986, One Man's Way, Penguin, Ringwood.

Holmes, Sandra Le Brun 1999, Faces in the Sun: Outback Journeys, Viking, Ringwood, Victoria.

Horne, Gerald 1986, Black and Red: W.E.B. Du Bois and the Afro-American Response to the Cold War 1944-1963, State University of New York Press, Albany.

- 1988, Communist Front? The Civil Rights Congress, 1946-1956, Associated University Presses, London and Toronto.

Horner, John 1960, 'Paul Robeson is Everyman', Adelaide Advertiser, 25 November 1960: 11.

Johnson, Audrey 1986, Fly a Rebel Flag: Bill Morrow, 1888-1980, Penguin, Ringwood.

Keiler, Allan 2002, Marian Anderson: a Singer's Journey, University of Illinois Press, Illinois.

Lake, Marilyn 2002, Faith: Faith Bandler, Gentle Activist, Allen \& Unwin, Sydney.

Maloney, Shane 2009, 'Faith Bandler and Paul Robeson', The Monthly, July 2009, accessed 30 September 2009: <http:/www.themonthly.com.au/encountersshane-maloney-faith-bandler-paul-robeson--1769>

Maynard, John 2007, Fight for Liberty and Freedom: The Origins of Australian Aboriginal Activism, Aboriginal Studies Press, Canberra.

McDonald, Tom 1994, interview with Richard Raxworthy, 23 August 1994, Labour Council of NSW Oral History Collection, National Library of Australia, Canberra.

McDonald, Tom and Audrey 1998, Intimate Union: Sharing a Revolutionary Life, Pluto Press, Sydney. 
Passionate Histories

McGrath, Pam and David Brooks forthcoming, 'Hard looking: the historical entanglements of the documentary film Manslaughter (1957)', Aboriginal History.

NSW Legislative Assembly, Hansard, 20 October 1998, accessed 3 January 2008: <www.parliament.nsw.gov.au/prod/parlment/HansArt.nsf/V3Key/ LA19981020036>

O'Reilly, Kenneth 1994, Black Americans: the FBI Files, Carroll and Graf, New York.

Patterson, William L 1971, The Man Who Cried Genocide: An Autobiography, International Publishers, New York.

Roadknight, Margret 2001, From the Folk Rag no 55, July 2001, accessed 2 October 2009: <http://users.tpg.com.au/folkrag/profiles/margrk.htm>

Stuart, Donald 1959, Yandy, Georgian House, Melbourne.

Taffe, Sue 2005, Black and White Together FCAATSI: The Federal Council for the Advancement of Aborigines and Torres Strait Islanders, 1958-1973, University of Queensland Press, St Lucia.

Taffe, Sue 2008, 'William Grayden', Collaborating for Indigenous Rights, NMA website, accessed 5 October 2009: <http://indigenousrights.net.au/person. asp?pID $=967>$

Von Eschen, Penny M 1997, Race against Empire: Black Americans and Anticolonialism 1937-1957, Cornell University Press, Ithaca and London.

Williams, Deane 1994, 'All that is left: the early life and work of Cecil Holmes', Metro 100: 36-39.

- 1999, 'Cecil Holmes', The Oxford Companion to Australian Film, Oxford University Press, Melbourne. 